\title{
PEMBERDAYAAN PETANI BAWANG MERAH MELALUI PENERAPAN SPO (STANDAR PROSEDUR OPERASIONAL) BAWANG MERAH SPESIFIK LOKASI YANG BERBASIS GAP (GOOD AGRICULTURAL PRACTICES)
}

\author{
Tavi Supriana ${ }^{1)}$, Rahmanta ${ }^{2)}$, Nurul Fajriah Pinem ${ }^{3)}$ \\ Fakultas Pertanian, Universitas Sumatera Utara
}

\begin{abstract}
Abstrak
Bawang merah merupakan komoditi yang penting karena dibutuhkan oleh masyarakat dan tidak ada barang substitusinya. Hal ini dapat dilihat dari permintaan yang terus meningkat. Peningkatan permintaan bawang merah tidak diikuti dengan peningkatan produksi, menyebabkan peningkatan harga bawang merah. Peningkatan harga biasanya akan direspon petani dengan meningkatkan produksi, tetapi hal ini tidak terjadi. Produksi bawang merah Sumatera Utara cenderung menurun. Selain itu, pemerintah juga menjadikan persoalan bawang merah tersebut menjadi prioritas program Bulog yang bertujuan untuk stabilitas harga dan produksi bawang merah. Untuk menjawab permasalahan produksi bawang merah ini, perlu dilakukan upaya berupa pelatihan pada petani bawang merah. Pelatihan dilaksanakan di Kecamatan Muara, Kabupaten Tapanuli Utara, karena memang Kecamatan Muara memiliki potensi yang paling mendukung untuk pengembangan usaha tani bawang merah. Pelatihan dari tim PPM USU diharapkan dapat meningkatkan keterampilan petani dalam melakukan budidaya bawang merah yang sesuai dengan Standar Prosedur Operasional (SPO) dengan menerapkan Good Agricultural Practices (GAP) serta pemahaman mengenai rantai pemasaran bawang merah. Keberhasilan hasil panen bawang merah di Kecamatan Muara diharapkan dapat menjadi contoh keberhasilan bagi kecamatan lainnya.
\end{abstract}

Kata kunci: bawang merah, produksi, pelatihan, SPO, GAP

\section{PENDAHULUAN}

Bawang merah termasuk dalam kelompok rempah yang tidak bersubstitusi, artinya fungsi bawang merah tidak dapat digantikan oleh bahan lain. Selain umbinya, daun bawang merah yang masih muda juga dapat dimanfaatkan sebagai bumbu. Tanaman bawang merah dapat ditanam dan tumbuh di dataran rendah sampai ketinggian 1000 meter dpl, namun pertumbuhan optimalnya adalah pada ketinggian 0-450 meter dpl. Sedangkan di dataran tinggi sampai dengan 1500 meter dpl, bawang merah cenderung berumur lama, ukuran umbinya lebih kecil, dan warna kulitnya kurang cerah sehingga kurang memikat (Ashari, 1995).

Salah satu provinsi penghasil bawang merah di Indonesia dengan luas lebih dari $1000 \mathrm{Ha}$ adalah Provinsi Sumatera Utara. Berdasarkan data pada tahun 2014, produksi bawang merah di Sumatera Utara hanya 7.810 ton, sedangkan konsumsi bawang merah di Sumatera Utara mencapai 25.503 ton. Ada kekurangan produksi bawang merah sebesar 17.693 ton. Jumlah impor bawang merah yang masuk ke Provinsi Sumatera Utara juga terus mengalami peningkatan dari tahun ke tahun. Perkembangan harga bawang merah sebenarnya berfluktuasi dengan cepat, tidak dalam tahunan, tetapi dari bulan kebulan (BPS Sumatera Utara, 2014).

Peningkatan harga bawang merah terjadi terus menerus dan tidak pernah terjadi penurunan. Dari sisi petani, peningkatan harga bawang merah tentu memberikan surplus kepada petani bawang merah dan mendorong petani untuk meningkatkan produksinya. Dari sisi penawaran, jika penawaran bawang merah elastis terhadap harga, maka semestinya peningkatan harga bawang merah akan diikuti dengan peningkatan produksi. Namun kenyataannya produksi tidak meningkat, malah cenderung menurun.

Agar produksi bwang merah dapat ditingkatkan, salah satu caranya adalah dengan melalui penerapan SPO (standar prosedur operasional) bawang merah spesifik lokasi yang berbasis GAP 
Tavi Supriana. et al. Pemberdayaan Petani Bawang Merah Melalui Penerapan SPO...

(Good Agricultural Practices) dan GHP (Good Handling Practices) bagi petani. Pelatihan GAP dan GHP dilakukan melalui sekolah lapang, di mana petani mampu meningkatkan produktivitas dan kualitas dalam menjaga kontinuitas ketersediaan dan mutu yang diminta oleh pasar serta mengarahkan produk yang tersertifikasi aman konsumsi dengan pengendalian OPT (Organisme Pengganggu Tanaman) yang ramah lingkungan.

Tapanuli Utara merupakan salah satu kabupaten di Provinsi Sumatera Utara yang menghasilkan bawang merah. Dari 15 kecamatan yang ada di Kabupaten Tapanuli Utara, hanya ada 2 kecamatan yang mengusahakan budidaya bawang merah, yaitu Kecamatan Muara dan Kecamatan Pagaran. Kecamatan Muara adalah kecamatan yang memiliki luas panen $87 \mathrm{Ha}$ dengan rata-rata produksi 8,316 Ton/Ha pada tahun 2015. Bawang merah dari Kecamatan Muara beraroma khas dan disukai konsumen. Kondisi alam yang sesuai dan tersedianya lahan kering yang cukup luas sangat potensial untuk dijadikan areal persawahan baru dan pertanaman bawang. Kecamatan Muara termasuk daerah Kabupaten Tapanuli Utara yang berada di kawasan Danau Toba, sehingga daerah ini mendapat pasokan air yang melimpah.

Dengan curah hujan yang cukup dan luas panen yang memadai, seharusnya Kecamatan Muara memiliki potensi besar untuk memproduksi bawang merah dengan jumlah produksi yang tinggi. Akan tetapi, kurangnya pemahaman mengenai teknik budidaya yang tepat dan sesuai dengan standar prosedur operasional, terutama pada penggunaan pupuk dan pestisida yang tidak tepat, menghambat produksi bawang merah itu sendiri. Disamping itu, banyak terdapat lahan kosong yang tidak dimanfaatkan oleh masyarakat.

Kecamatan ini juga memiliki potensi besar untuk memproduksi padi. Padahal, jika masyarakat memiliki pemahaman lebih mengenai pertanian, masyarakat akan tahu bahwa tanaman bawang merah baik untuk ditanam dekat dengan tanaman padi atau ditanam pada saat masa lahan tidur. Tanaman bawang merah dapat meremahkan tanah sehingga tanah memiliki tekstur yang lebih baik ketika masyarakat akan menanam padi kembali.

Masyarakat petani di Kecamatan Muara umumnya hidup di garis kemiskinan.

Rendahnya produksi bawang merah di daerah ini juga turut menurunkan penghasilan masyarakat petani. Sebenarnya wilayah ini memiliki potensi yang baik untuk meningkatkan hasil produksinya, akan tetapi lemahnya pengetahuan masyarakat dan minimnya permodalan mengakibatkan peningkatan menjadi terhambat. Kelompok tani Sahora dan kelompok tani Sempurna yang ada di desa Batubinumbun Kecamatan Muara ini dapat dijadikan wadah bagi masyarakat untuk bekerja sama dan belajar mengembangkan pertanian bawang merah di daerah mereka. Hanya saja, kedua kelompok tani ini belum berjalan sesuai dengan fungsinya. Di sisi lain, kurangnya kemauan masyarakat untuk memanfaatkan lahan pun turut mempengaruhi rendahnya produksi bawang merah. Padahal lahan di daerah ini cukup berpotensi mengingat daerah ini mendapat curah hujan yang cukup. Untuk itu, pemanfaatan lahan ini harus lebih dioptimalkan lagi.

\section{METODE}

Program PPM Mono Tahun dengan dana Non PNBP dilaksanakan di Kecamatan Muara Kabupaten Tapanuli Utara. Kegiatan berlangsung selama 6 bulan sejak awal kegiatan hingga penyerahan laporan kegiatan.

Metode pendekatan yang ditawarkan bagi wilayah sasaran sebagai berikut.

1. Pelatihan SPO (Standar Prosedur Operasional) spesifik lokasi budidaya tanaman bawang merah.

2. Pelatihan cara penggunaan MOD dan aplikasi pupuk organik pada budidaya bawang merah.

3. Pelaksanaan pemeliharaan tanaman bawang merah dan teknik pengairan.

4. Sosialisasi teknik pasca panen dan tata niaga bawang merah.

5. Melakukan penanaman bawang merah secara langsung di lapangan dengan menggunakan metode GAP (Good Agricultural Practices).

Kegiatan ini dilakukan di balai pertemuan masyarakat Kecamatan Muara dan lahan penanaman bawang merah. Kegiatan ini dilakukan sedemikian rupa sehingga mudah 
Tavi Supriana. et al. Pemberdayaan Petani Bawang Merah Melalui Penerapan SPO...

dipahami dan dimengerti oleh masyarakat. Penggunaan peralatan berupa LCD proyektor merupakan sarana vital digunakan sehingga akan lebih menambah ketertarikan masyarakat tentang topik yang disampaikan.

Tahap pembelajaran praktek dan pelaksanaan kegiatan sebagai berikut.

1. Pembelajaran tentang pengenalan syarat tumbuh
a. Iklim
b. Tanah

2. Pembelajaran tentang teknik penanaman
a. Pola tanam
b. Pemilihan varietas
c. Umbi bibit
d. Kerapatan tanaman
e. Pengolahan tanah
f. Penanaman dan pemupukan

g. Pengairan

h. Pengendalian hama dan penyakit

i. Pemanenan

3. Pembelajaran tentang cara penggunaan Mikro Organisme Dekomposer (MOD)

Pada program PPM Mono Tahun dana Non PNBP tahun 2016 ini tim PPM USU yang terlibat dalam kegiatan PPM ini terdiri atas 3 orang dosen. Ketiga dosen ini merupakan tim pelaksana yang terlibat langsung dengan aktivitas pengembangan bawang merah di desa ini sehingga kepakaran dosen pada kegiatan-kegiatan yang berkaitan dengan keberhasilan program mutlak diperlukan. Adapun tim pelaksana PPM ini adalah sebagai berikut.
1. Nama Lengkap

Jabatan

Fakultas/P.Studi

Bidang Keahlian

Tugas dalam Kegiatan

\section{Nama Lengkap}

Jabatan

Fakultas/P.Studi

Bidang Keahlian

Tugas dalam Kegiatan

3. Nama Lengkap

Jabatan

Fakultas/P.Studi

Bidang Keahlian

Tugas dalam Kegiatan
: Dr. Ir. Tavi Supriana, M.S

: Ketua Tim Pelaksana

: Pertanian/Agribisnis

: Agribisnis

- Melakukan FGD dengan masyarakat mengenai bawang merah

- Melakukan penyuluhan dan pelatihan SPO spesifikasi lokasi budidaya bawang merah

- Melakukan penyuluhan dan pelatihan cara penggunaan MOD dan aplikasi pupuk organik spesifikasi lokasi

- Mengawasi keberhasilan budidaya dan pasca penen bawang merah

- Evaluasi hasil implementasi iptek yang digunakan

: Dr. Ir. Rahmanta, M.Si

: Anggota Tim Pelaksana

: Pertanian/Agribisnis

: Agribisnis

- Sebagai anggota ikut mengorganisir seluruh kegiatan

- Merencanakan teknologi iptek yang digunakan dan mengawasi jalannya kegiatan

- Membantu dalam penyuluhan dan pelatihan

- Turut serta dalam evaluasi hasil implementasi iptek yang digunakan

: Nurul Fajriah Pinem, SP, MP

: Anggota Tim Pelaksana

: Pertanian/Agribisnis

: Agribisnis

- Sebagai anggota ikut mengorganisir seluruh kegiatan

- Merencanakan teknologi iptek yang digunakan dan mengawasi jalannya kegiatan

- Membantu dalam penyuluhan dan pelatihan 
Tavi Supriana. et al. Pemberdayaan Petani Bawang Merah Melalui Penerapan SPO...

- Turut serta dalam evaluasi hasil implementasi iptek yang digunakan

Selain itu Tim Pakar juga didukung oleh dukungan USU melalui Lembaga Penelitian USU dan LPPM USU yang siap memberikan dukungan pengetahuan dan pengalaman. Untuk meningkatkan kinerja Tim Pakar juga dibantu oleh mahasiswa USU yang siap melakukan kegiatan PPM bagi masyarakat sekitar daerah penelitian, yang jumlahnya disesuaikan dengan kebutuhan.

\section{HASIL DAN PEMBAHASAN}

Program Pengabdian pada Masyarakat Mono Tahun telah dilaksanakan di Kecamatan Muara Kabupaten Tapanuli Utara. Kunjungan diawali dengan acara perkenalan tim pengabdian. Kegiatan pelatihan SPO (Standar Prosedur Operasional) Bawang Merah Spesifik Lokasi yang Berbasis GAP (Good Agricultural Practices) di Kecamatan Muara Kabupaten Tapanuli Utara dilaksanakan pada hari Minggu tanggal 17

Oktober 2012. Kegiatan dimulai pukul 09.00 sampai dengan pukul 18.00 WIB. Kegiatan diawali dengan mengumpulkan peserta di Kantor Camat Muara sebagai tempat pelatihan. Panitia pelatihan sebanyak 45 orang pegawai Kantor Camat Muara. Peserta pelatihan sebanyak 40 orang petani bawang merah. Tabel 4.1 menunjukkan jadwal kegiatan pelatihan yang telah dilakukan.

Tabel 4.1. Jadwal Kegiatan Pelatihan SPO (Standar Prosedur Operasional) Bawang Merah Spesifik Lokasi yang Berbasis GAP (Good Agricultural Practices)

\begin{tabular}{|l|l|l|}
\hline No & Kegiatan & Waktu \\
\hline 1 & Perkenalan dan wawancara awal & $09.00-10.00$ \\
\hline 2 & $\begin{array}{l}\text { Pelatihan SPO bawang merah spesifik lokasi yang berbasis } \\
\text { GAP }\end{array}$ & $10.00-13.00$ \\
\hline 3 & Istirahat & $13.00-14.00$ \\
\hline 4 & Demonstrasi cara penggunaan MOD & $14.00-15.00$ \\
\hline 5 & Kunjungan ke lahan percontohan & $15.00-16.00$ \\
\hline 6 & Kunjungan ke tempat pembibitan & $16.00-16.30$ \\
\hline 7 & Kunjungan ke tempat pemasaran bawang & $16.30-18.00$ \\
\hline
\end{tabular}

Kegiatan awal dari program pengabdian ini dilakukan dengan melakukan perkenalan dan wawancara awal untuk mengetahui kondisi pengetahuan petani bawang merah di Kecamatan Muara Kabupeten Tapanuli Utara. Dari hasil wawancara, diperoleh informasi awal bahwa para petani sudah biasa bertani bawang merah, namun persoalan yang muncul adalah minimnya pengetahuan mengenai SPO (Standar Prosedur Operasional) Bawang Merah spesifik lokasi yang Berbasis GAP (Good Agricultural Practices) sehingga produksi yang dihasilkan rendah.

Setelah perkenalan, dilaksanakan kegiatan pelatihan berupa penyuluhan mengenai SPO (Standar Prosedur Operasional) Bawang Merah spesifik lokasi yang Berbasis GAP (Good Agricultural Practices) dan demonstrasi cara penggunaan MOD (Mikro Organisme Dekomposer).
Pelaksanan kegiatan ini dilakukan oleh 4 (tiga) orang tim pengabdi. Tim pengabdian memberikan presentasi mengenai SPO (Standar Prosedur Operasional) Bawang Merah spesifik lokasi yang Berbasis GAP (Good Agricultural Practices). Kegiatan pelatihan yang dilaksanakan dengan acara tatap muka dan demonstrasi cara penggunaan MOD berjalan dengan baik dan lancar. Acara kemudian dilanjutkan sesi tanya jawab. Berbagai pertanyaan diajukan secara antusias oleh para peserta dalam sesi tanya jawab. Peserta terlihat antusias mengikuti kegiatan ini. Setelah sesi tanya jawab selesai dilanjutkan dengan penyerahan bentuan berupa bibit bawang merah dan MOD kepada petani. Kegiatan diakhiri dengan kunjungan ke lahan percontohan, tempat pembibitan, dan tempat pemasaran bawang merah

Program pengabdian pada masyarakat berupa pelatihan dan pemberian bantuan yang 
Tavi Supriana. et al. Pemberdayaan Petani Bawang Merah Melalui Penerapan SPO...

sudah dilaksanakan ini diharapkan dapat menambah pengetahuan dan keterampilan bagi petani sehingga mampu meningkatkan produksi bawangnya. Diharapkan petani akan lebih semangat dan termotivasi untuk meningkatkan produksi bawang merah. Hasil pelatihan ini akan bermanfaat bagi petani dan masyarakat.

Tahapan kegiatan yang dilakukan sebagai berikut.

1. Perkenalan
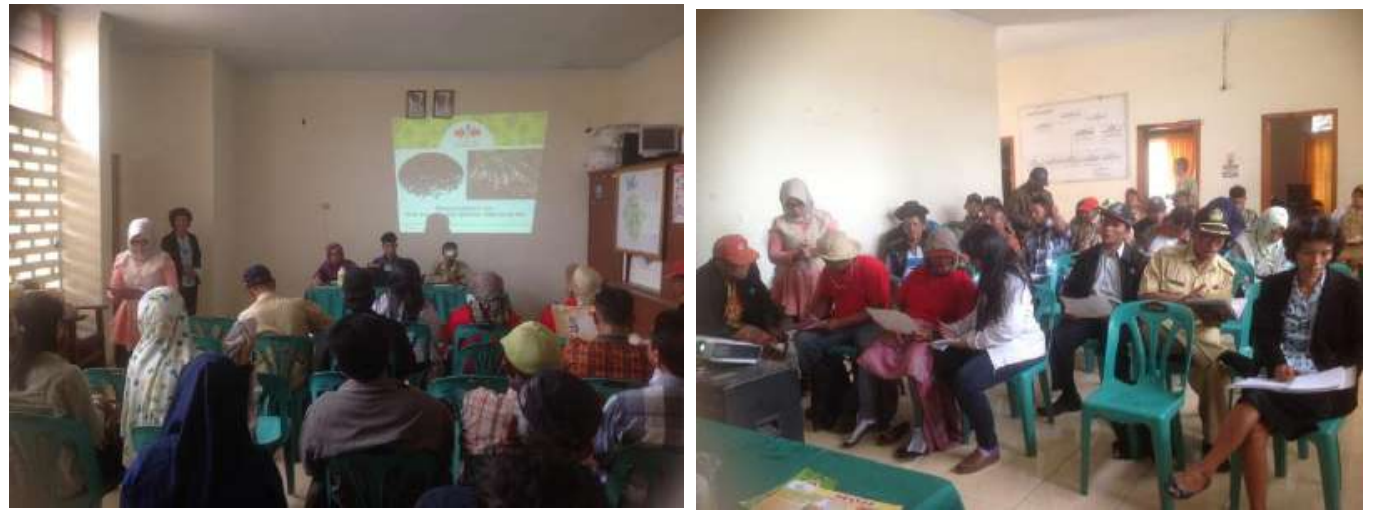

Gambar 3.1. Kegiatan Perkenalan dengan Petani Bawang Merah Peserta Pelatihan

2. Penyuluhan dari Pemateri I (Pegawai Dinas Pertanian)
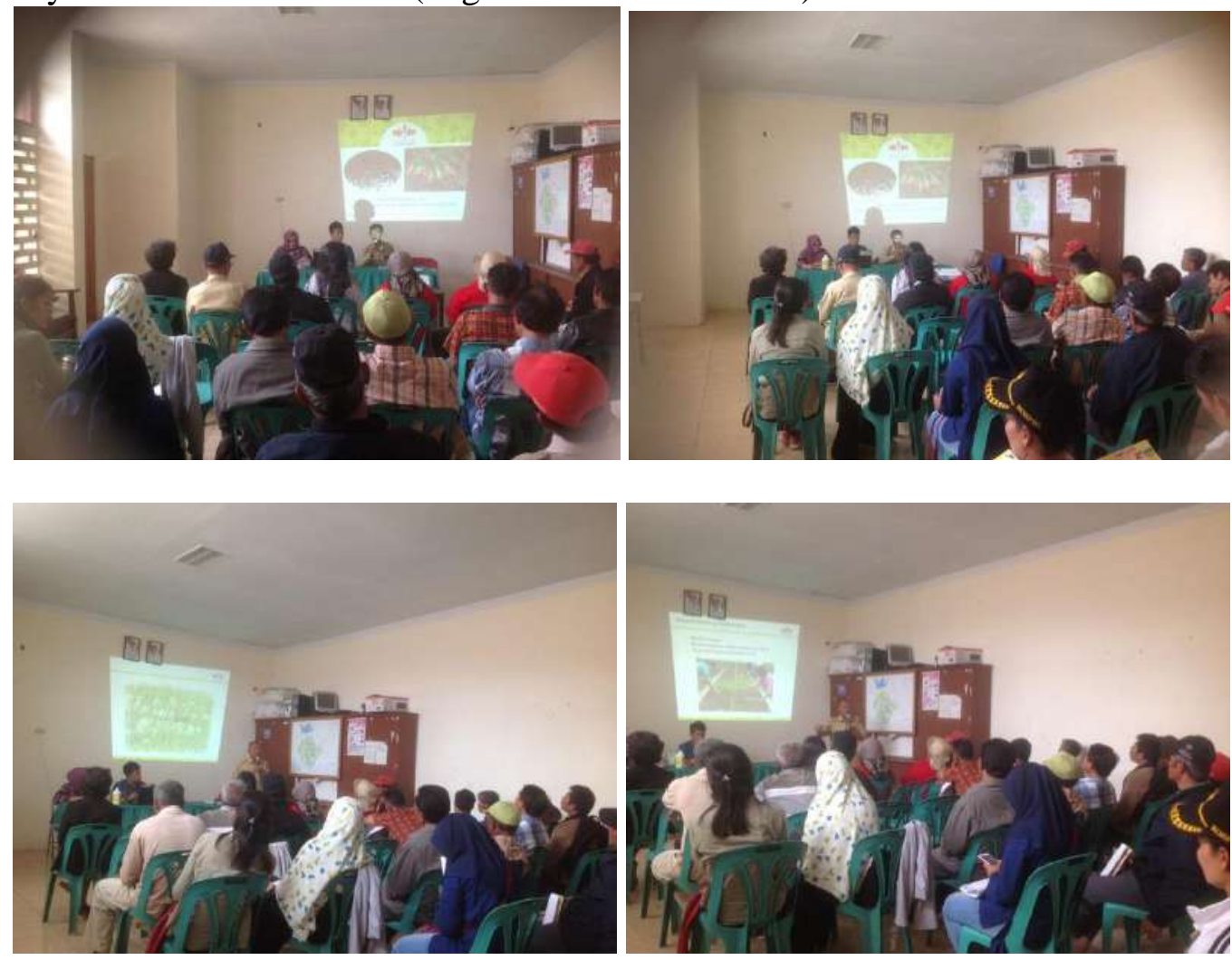
Tavi Supriana. et al. Pemberdayaan Petani Bawang Merah Melalui Penerapan SPO...
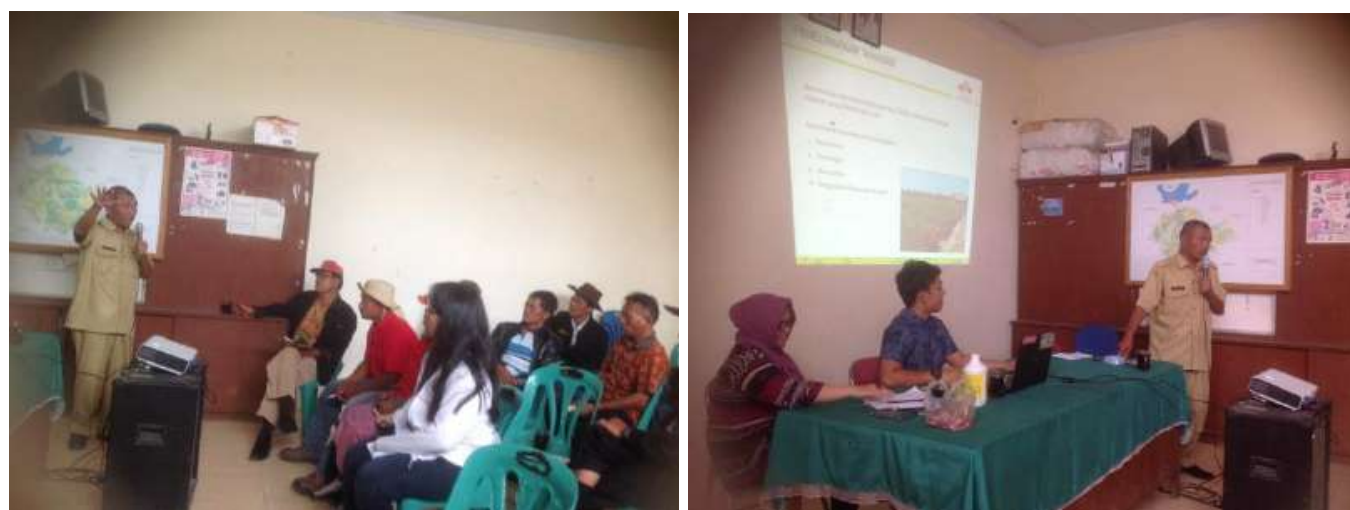

Gambar 3.2. Kegiatan Penyuluhan oleh Pegawai Dinas Pertanian

3. Penyuluhan dari Pemateri II (Dosen Fakultas Pertanian USU)
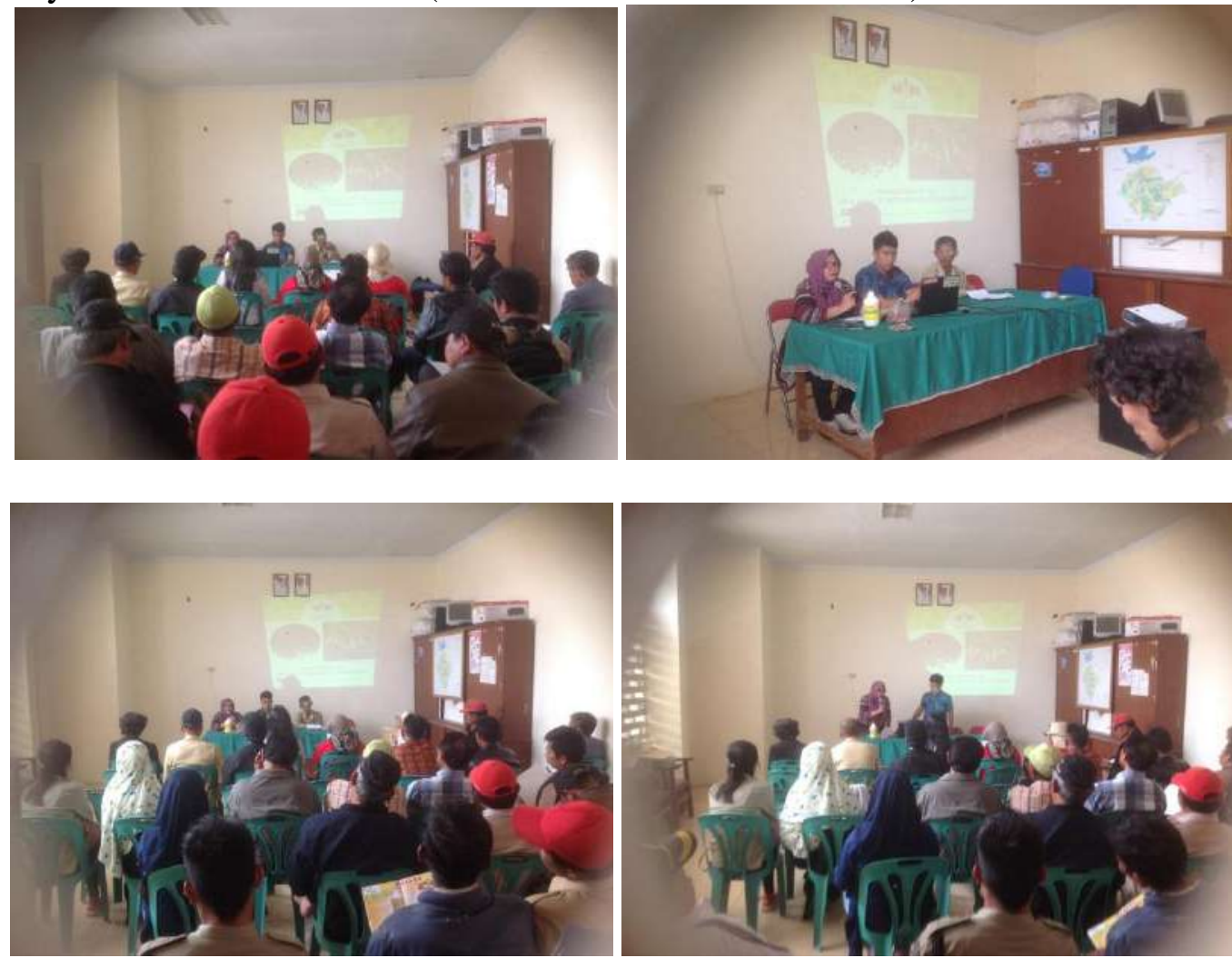

Gambar 3.3. Kegiatan Penyuluhan oleh Dosen Fakultas Pertanian USU

4. Penyuluhan dari Pemateri III (Sesama Petani Bawang Merah)
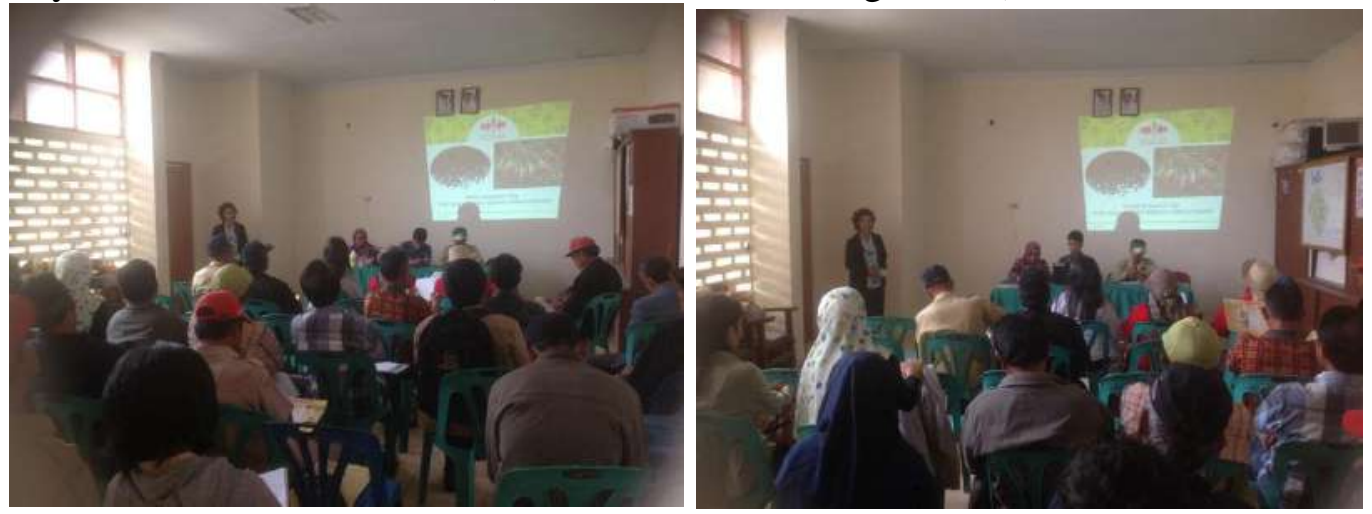
Tavi Supriana. et al. Pemberdayaan Petani Bawang Merah Melalui Penerapan SPO...
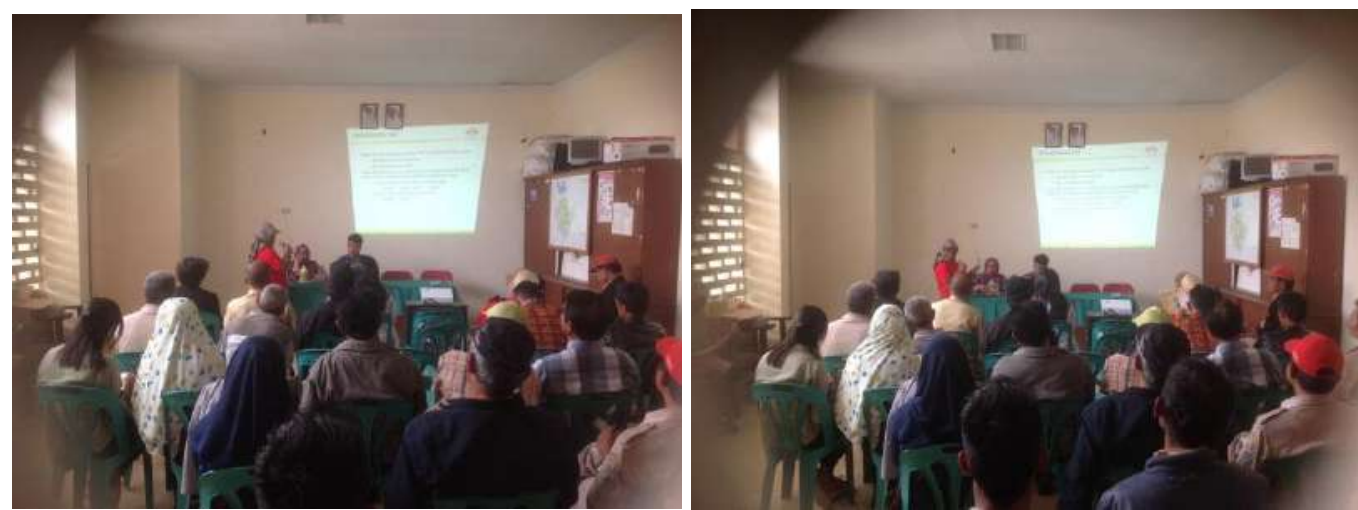

Gambar 3.4. Kegiatan Penyuluhan oleh Sesama Petani Bawang Merah

5. Demonstrasi Cara Penggunaan MOD
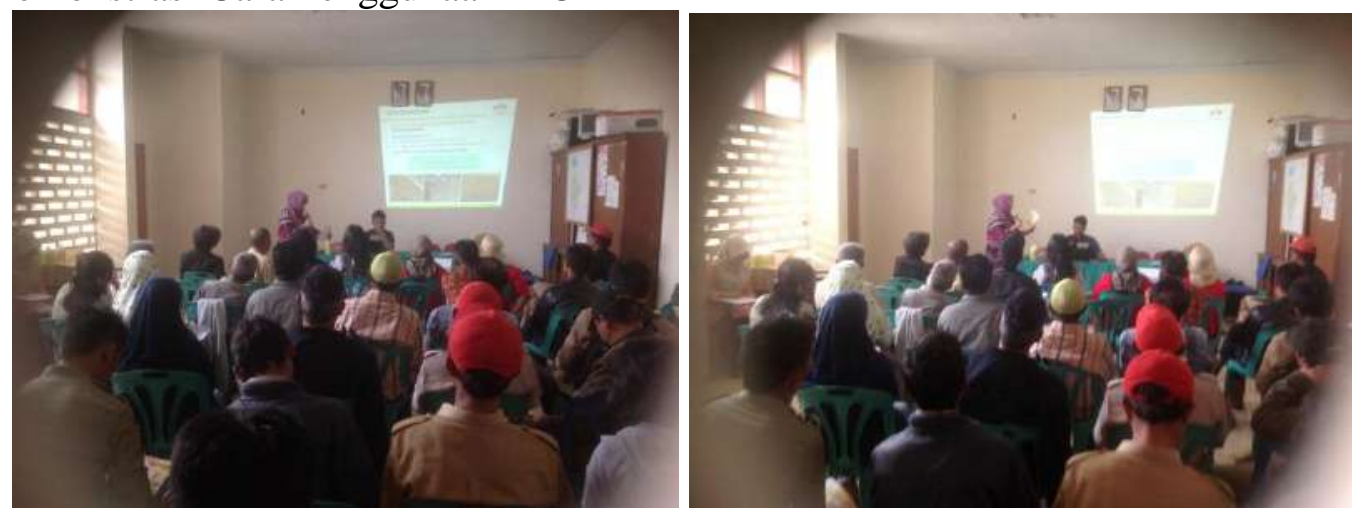

Gambar 3.5. Kegiatan Demonstrasi Cara Penggunaan MOD oleh Dosen Fakultas Pertanian USU

6. Tanya Jawab
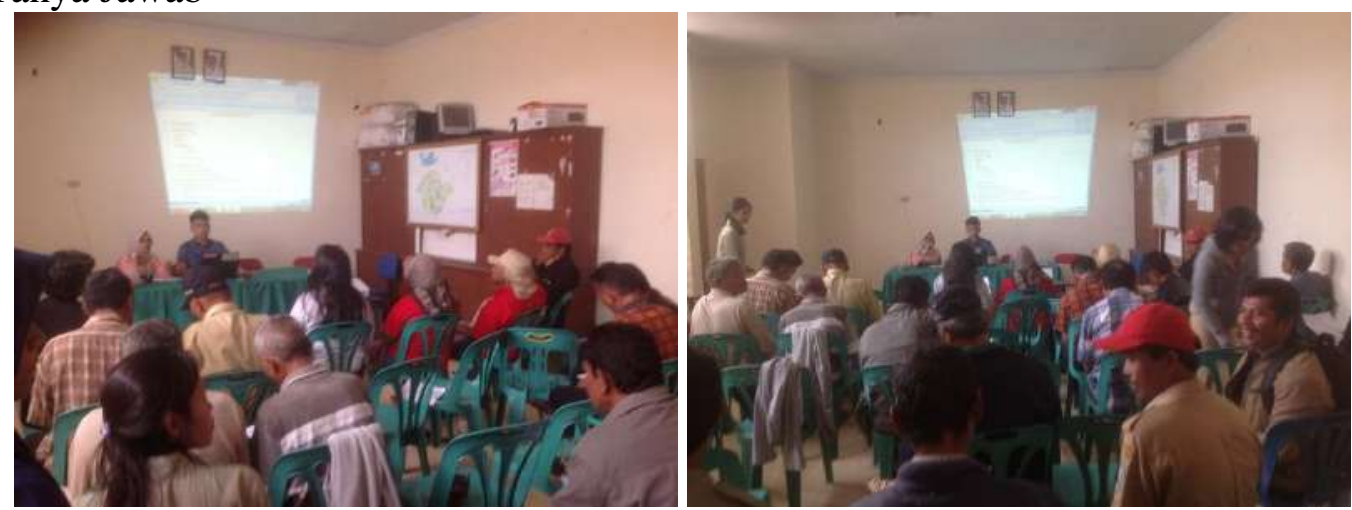
Tavi Supriana. et al. Pemberdayaan Petani Bawang Merah Melalui Penerapan SPO...
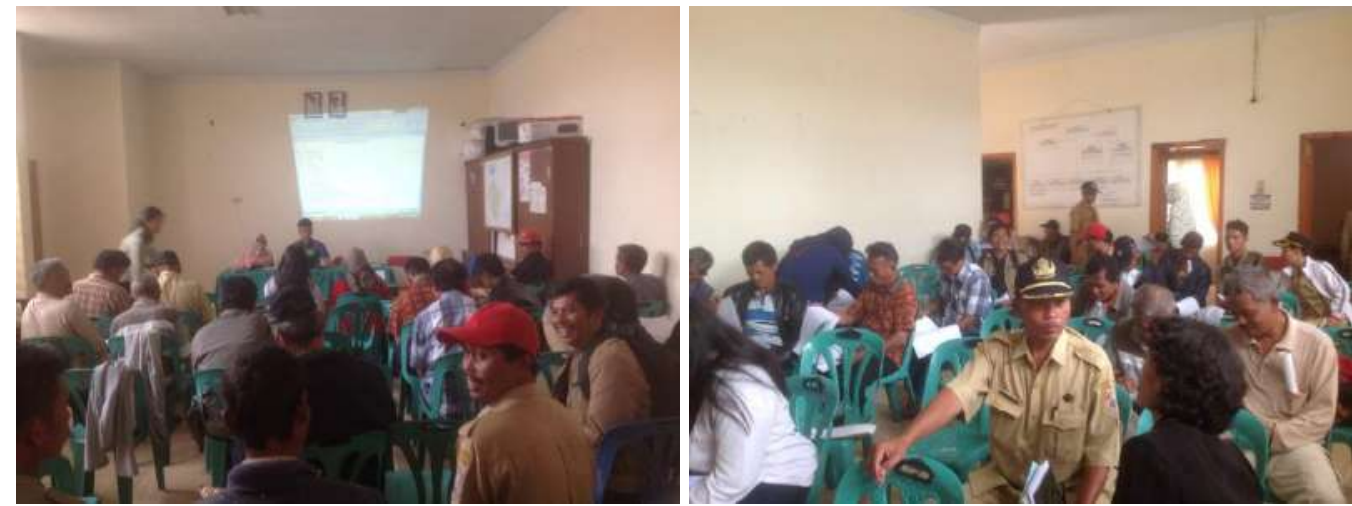

Gambar 3.6. Kegiatan Tanya Jawab dengan Petani Bawang Merah Peserta Pelatihan

7. Penyerahan bantuan bibit bawang merah

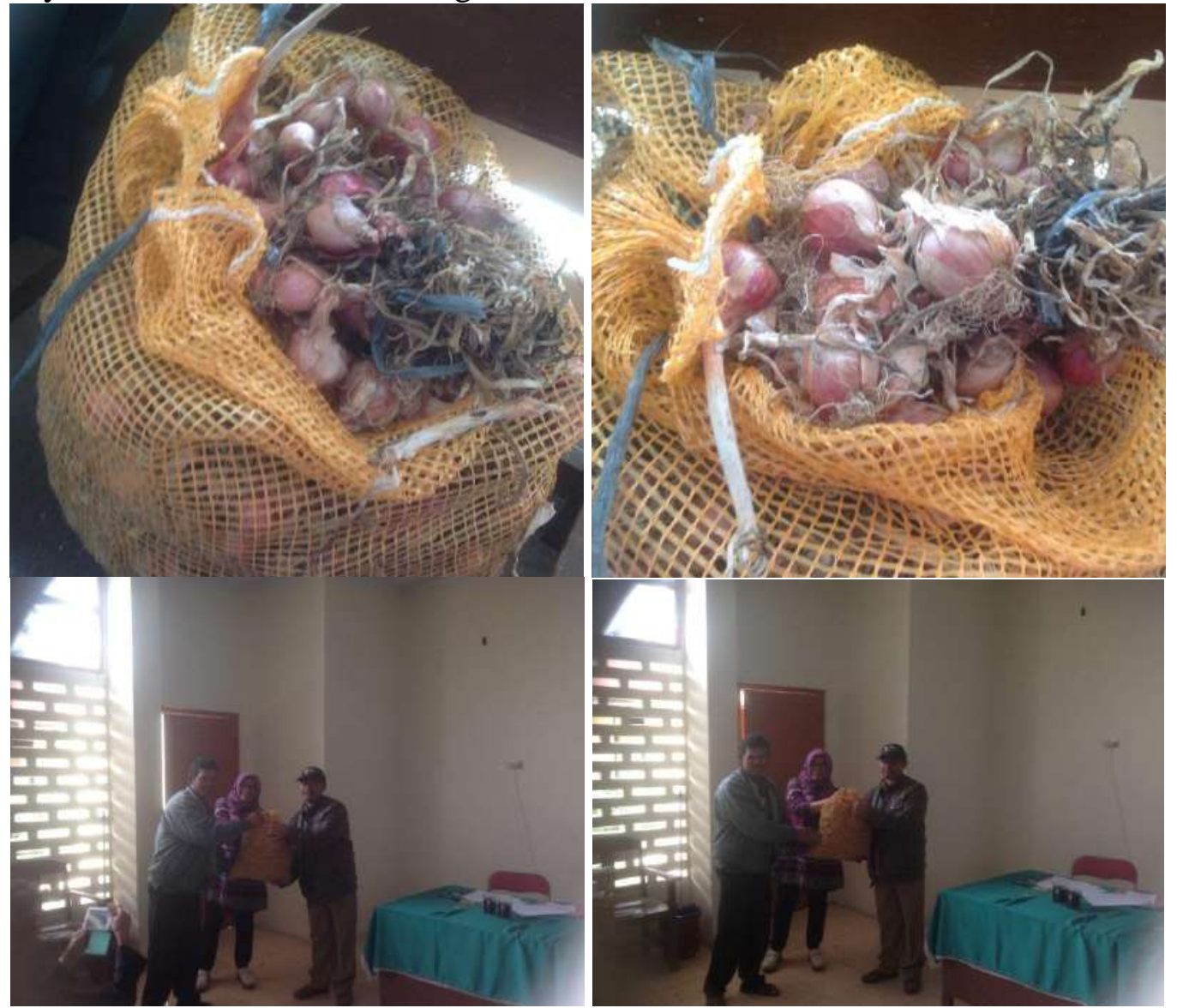

Gambar 3.7. Kegiatan Penyerahan bantuan Bibit Bawang Merah kepada Petani

8. Penyerahan bantuan MOD 
Tavi Supriana. et al. Pemberdayaan Petani Bawang Merah Melalui Penerapan SPO...

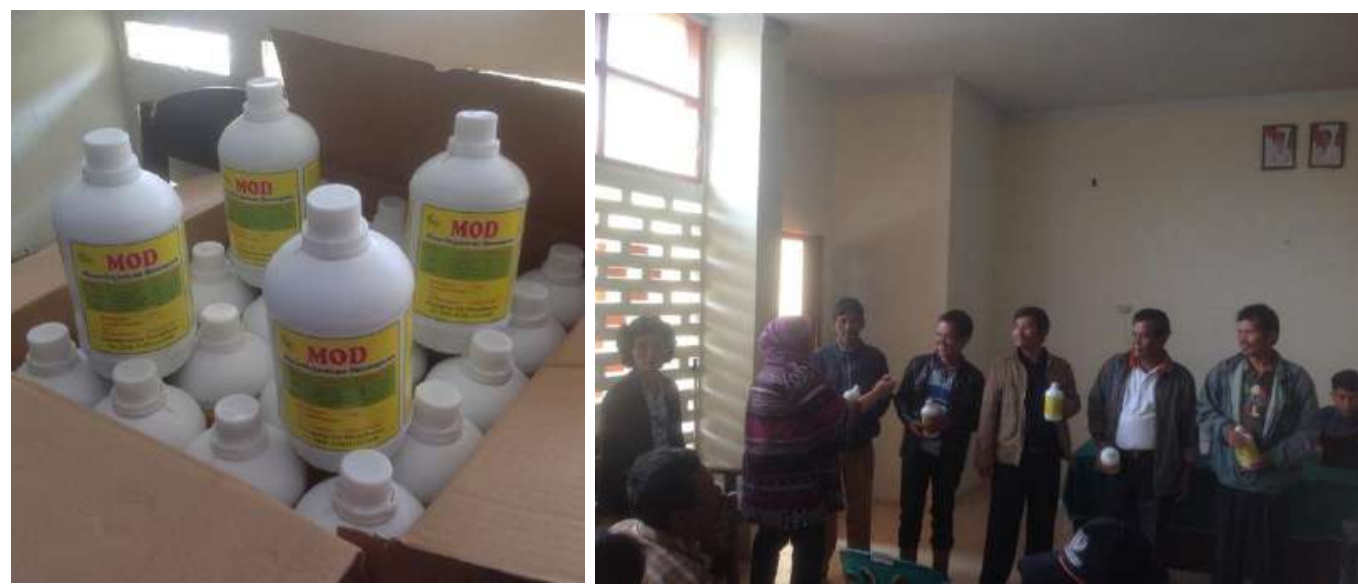

Gambar 3.8. Kegiatan Penyerahan bantuan MOD kepada Petani

9. Mengunjungi lokasi lahan percontohan
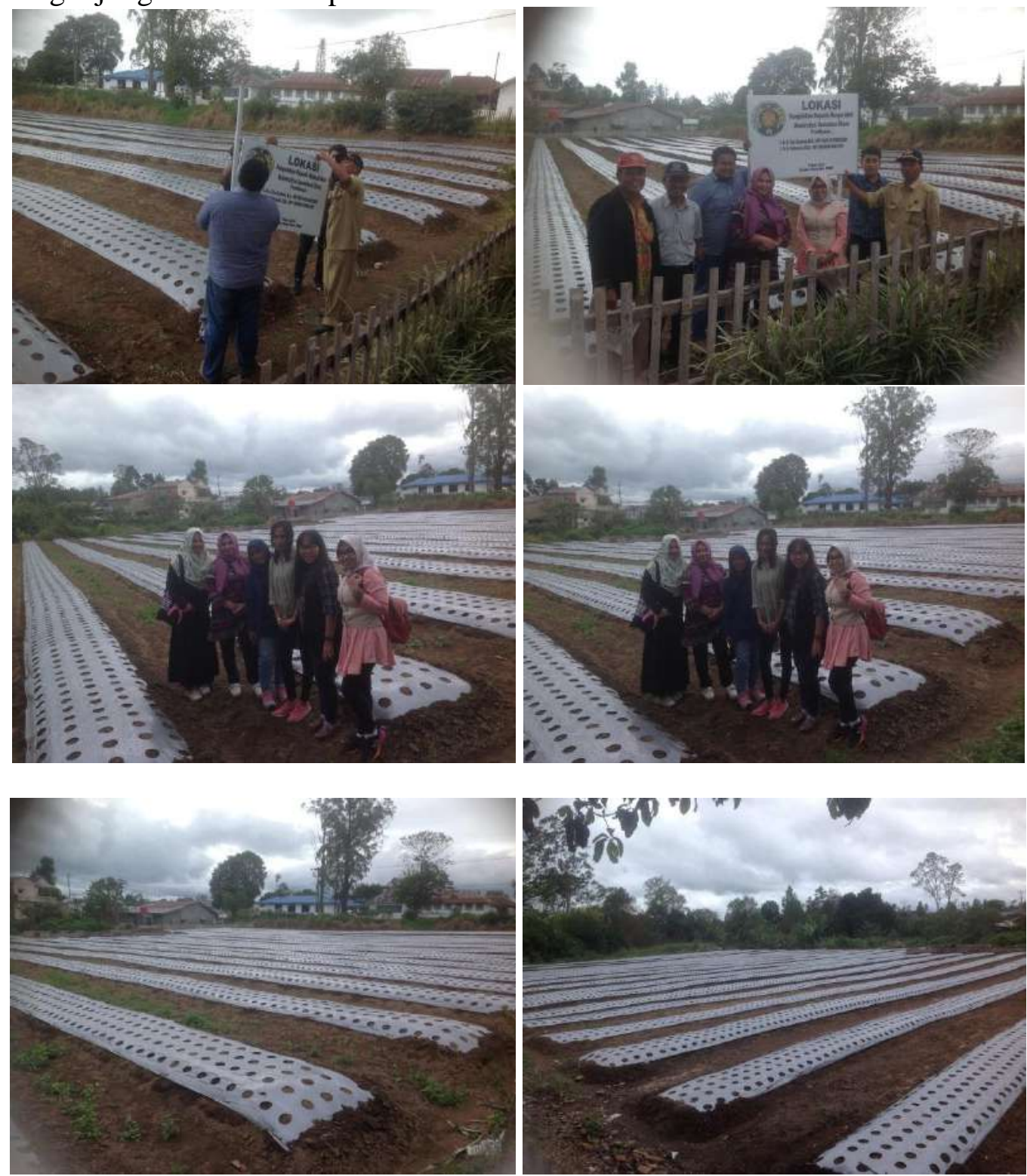

Gambar 3.9. Kegiatan Pemasangan Plakat dan Kunjungan ke Lokasi Lahan Percontohan 
Tavi Supriana. et al. Pemberdayaan Petani Bawang Merah Melalui Penerapan SPO...

10. Kunjungan ke tempat pembibitan bawang merah
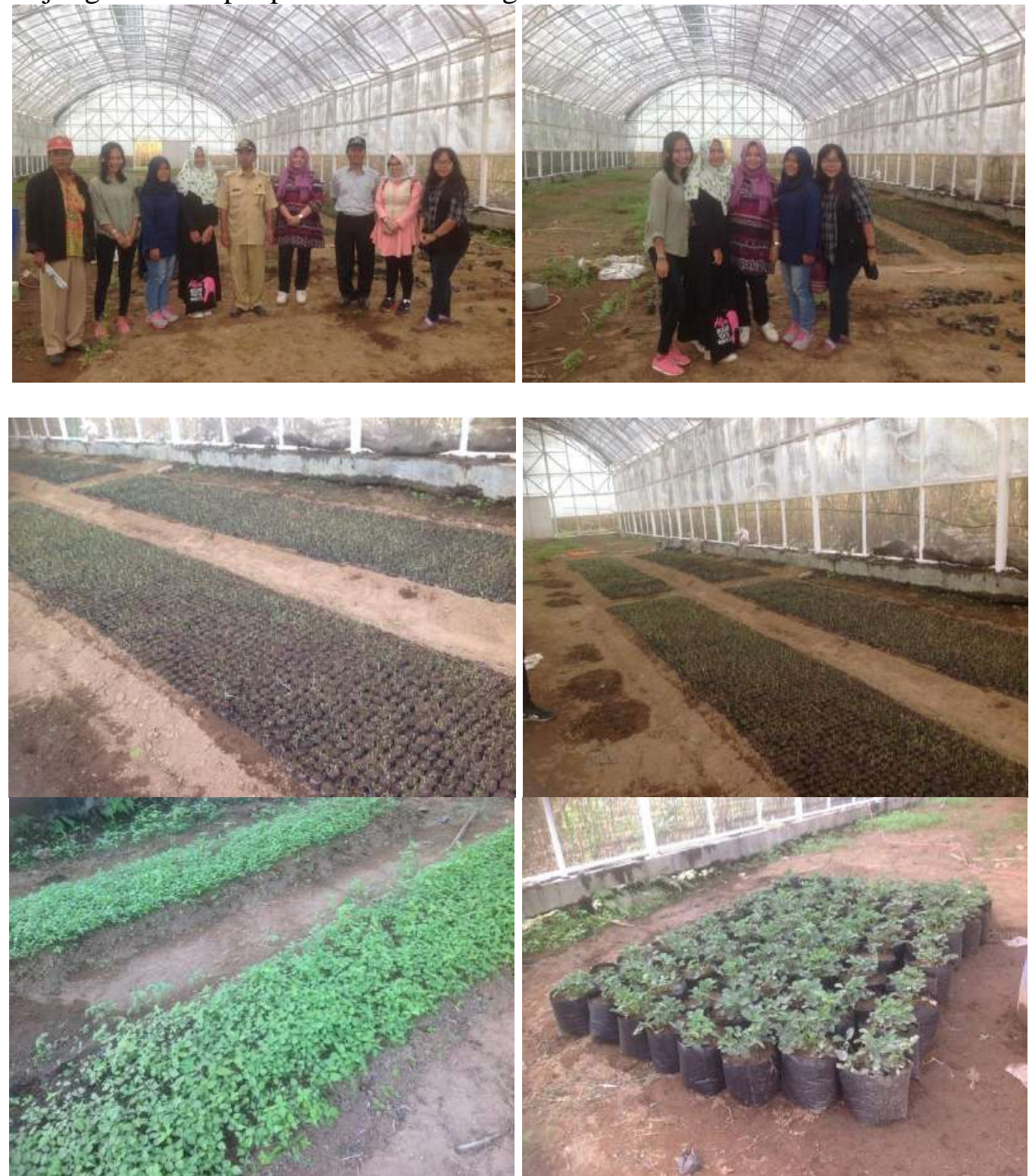

Gambar 3.10. Kegiatan Kunjungan ke Tempat Pembibitan Bawang Merah

11. Kunjungan ke tempat pemasaran bawang merah
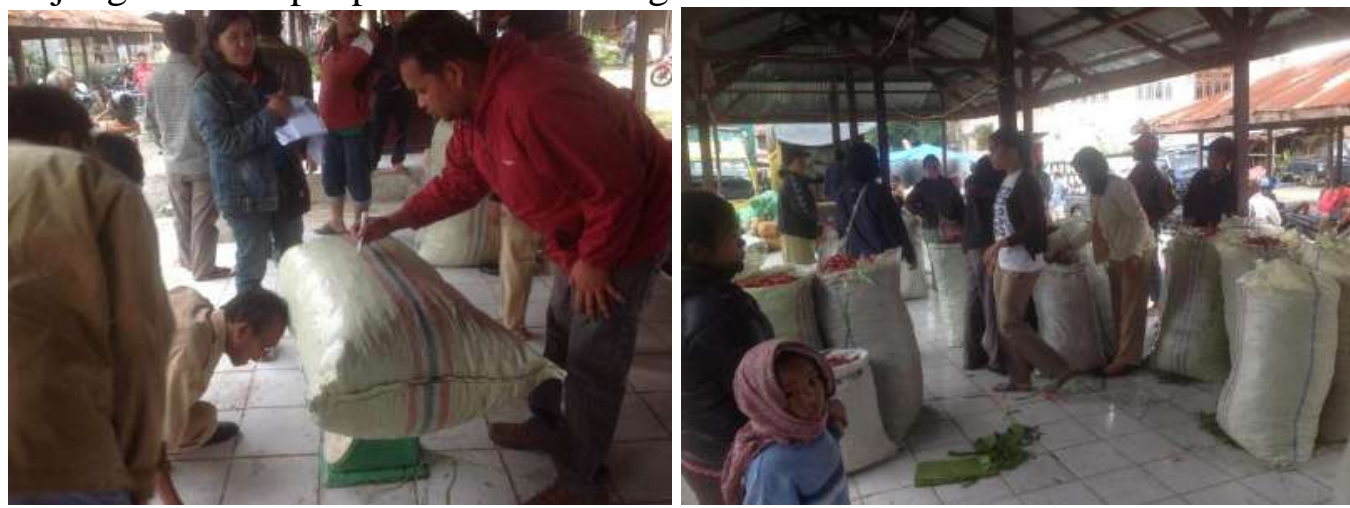
Tavi Supriana. et al. Pemberdayaan Petani Bawang Merah Melalui Penerapan SPO...
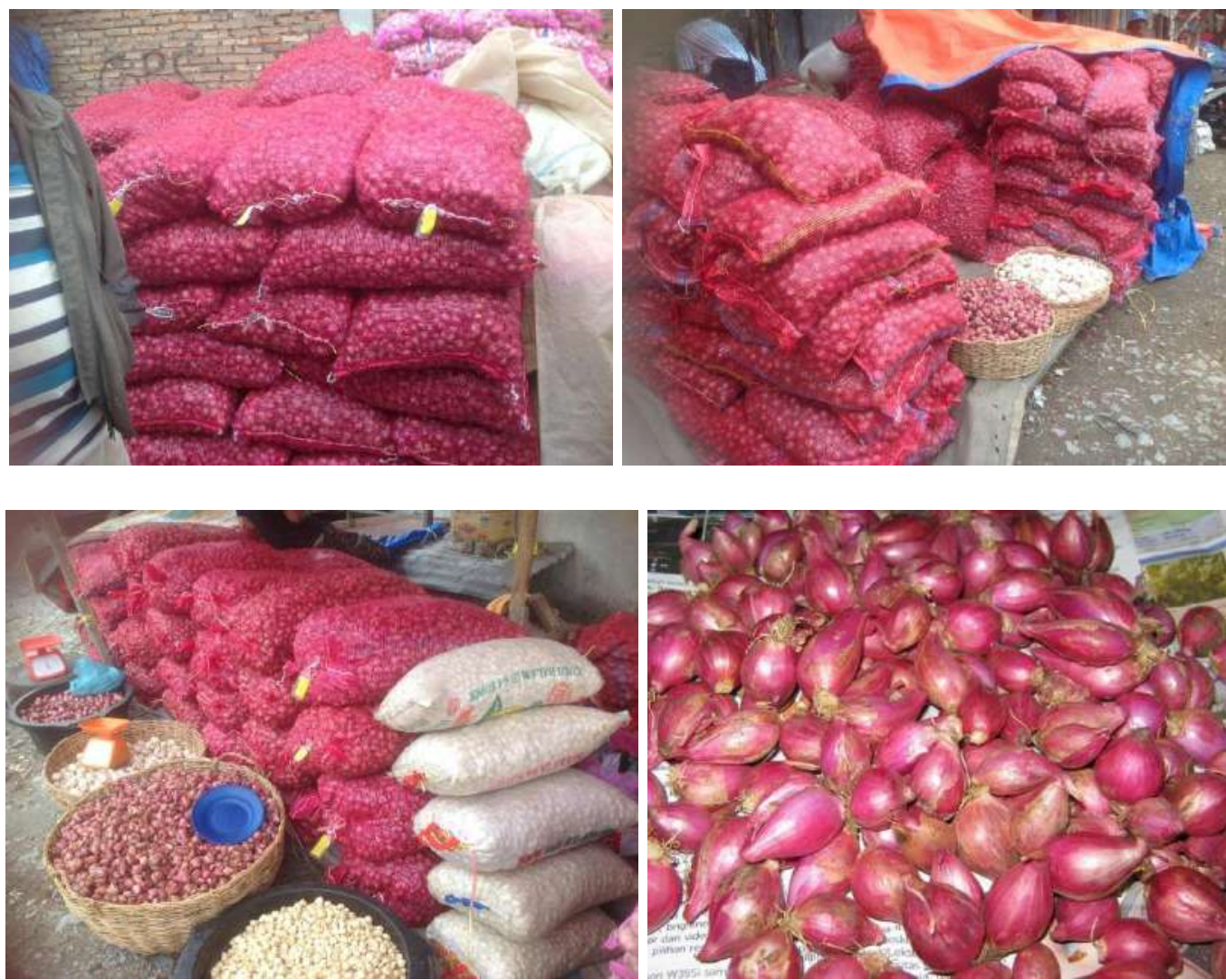

Gambar 3.11. Kegiatan Kunjungan ke Pasar Bawang Merah

12. Tim Pelaksana setelah Selesai Kegiatan

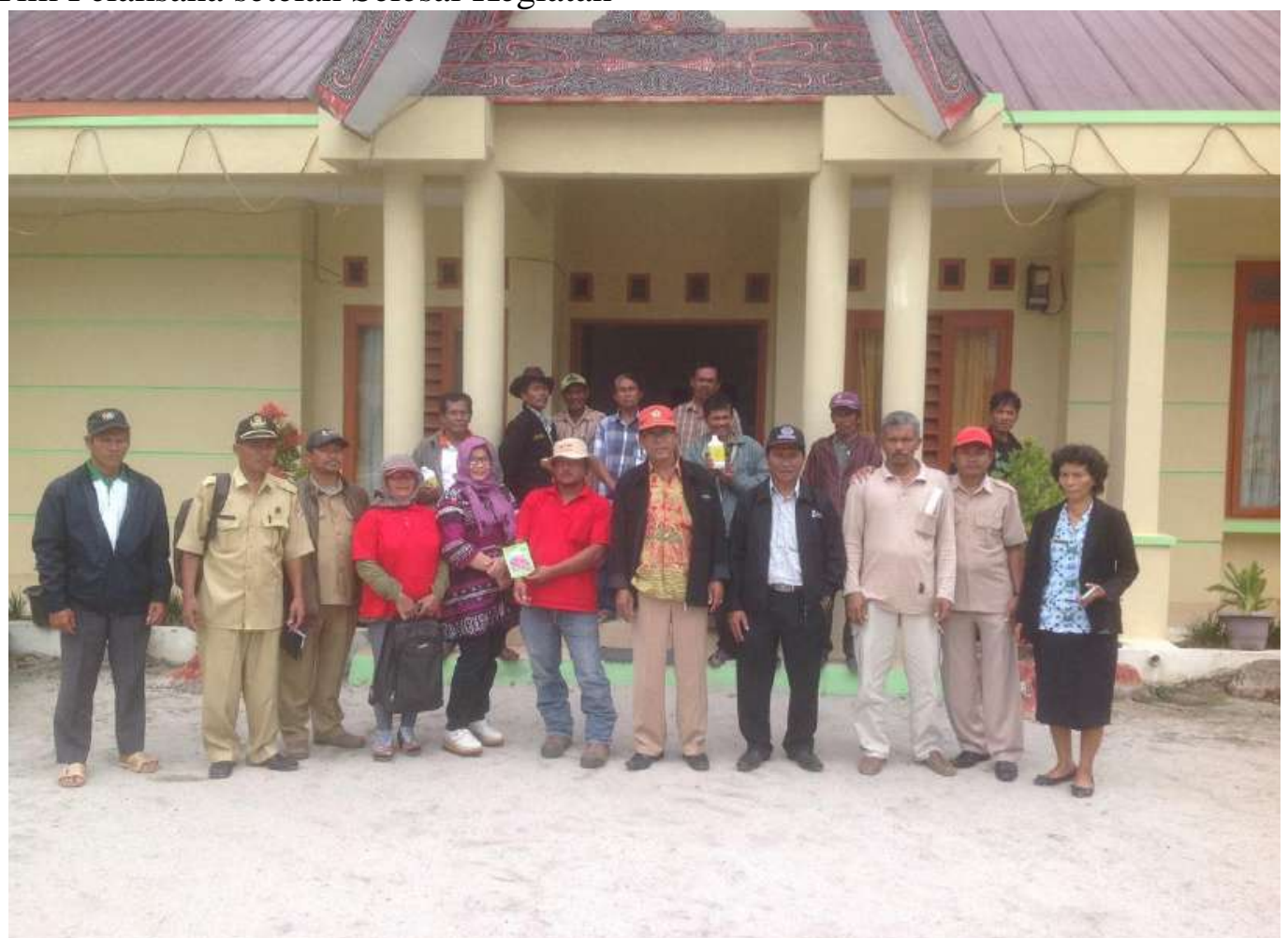

Gambar 3.12. Berfoto Bersama Tim Pelaksana setelah Selesai Kegiatan 
Tavi Supriana. et al. Pemberdayaan Petani Bawang Merah Melalui Penerapan SPO...

Keberhasilan pelaksanaan program pengabdian masyarakat ini dilihat dari dua tolak ukur sebagai berikut.

\section{Respons positif dari peserta pelatihan}

Respons peserta pelatihan diobservasi selama pelatihan berlangsung dengan melihat antusiasme peserta pelatihan selama berlangsungnya kegiatan. Berdasarkan hasil kegiatan, kegiatan pengabdian ini mendapat respon yang positif dari para peserta, dimana para peserta sangat antusias mengikuti kegiatan dari awal sampai akhir, dan hasilnya juga sangat baik.

2. Meningkatnya keterampilan peserta setelah mendapat pelatihan

Dari hasil evaluasi yang diperoleh selama pelaksanaan kegiatan ini, dapat disimpulkan bahwa program ini telah mampu memberikan manfaat yang sangat besar dan tepat sasaran bagi khalayak petani bawang yang menjadi khalayak sasaran dalam kegiatan ini. Bentuk pelatihan seperti ini merupakan bentuk yang sangat efektif untuk memberikan penyegaran dan tambahan wawasan serta pengetahuan baru di bidang pertanian untuk memberikan rangsangan kepada petani supaya bisa meningkatkan produksinya.

\section{KESIMPULAN}

Dari kegiatan pengabdian pada masyarakat ini dapat disimpulkan bahwa:

1. Pengetahuan dan pemahaman petani bawang merah di Kecamatan Muara Kabupaten Tapanuli Utara menjadi meningkat.

2. Keterampilan petani bawang merah di Kecamatan Muara Kabupaten Tapanuli Utara semakin meningkat.

Mengingat besarnya manfaat kegiatan pengabdian pada masyarakat ini, maka selanjutnya perlu:

1. Mengadakan sosialisasi dan pelatihan serupa pada petani bawang merah di Kecamatan yang lain, dengan materi yang sama.

2. Adanya kesinambungan program pasca kegiatan pengabdian ini sehingga para petani bawang merah benar-benar dapat meningkatkan produksinya.

\section{REFERENSI}

Ashari, S. 1995. Hortikultura Aspek Budaya. UI Press. Jakarta.Anatan, L., dan Ellitan, L. 2008. Supply Chain Management, Teori dan Aplikasi. Alfabeta. Bandung.

Balitbang Pertanian, 2005. Pusat Penelitian dan Pengembangan Hortikultura. Available at http://hortikultura.Litbang Pertanian.go.id.

Brahmantyo, A. 2014. Tata Niaga Bawang Merah (Studi Kasus Desa Parangtritis, Kecamatan Kretek, Kabupaten Bantul, DIY Tahun 2014). Universitas Atmajaya. Yogyakarta.

BPS, Badan Pusat Statistik Sumatera Utara. 2014. Perkembangan Luas Panen, dan Produksi Bawang Merah di Indonesia

BPS, Badan Pusat Statistik Sumatera Utara. 2014. Impor Bawang Merah Ke Provinsi Sumatera Utara

Daniel, M. 2002. Pengantar Ekonomi Pertanian. Bumi Aksara. Jakarta.

Gaspersz, V. 2000. Ekonomi Manajerial dalam Pembuatan Keputusan Bisnis. PT Gramedia Pustaka Utama. Jakarta.

Gujaratti, D. 1995. Ekonomi Dasar (diterjemahkan oleh Sumarno Zain). Erlangga. Jakarta.

Gunadi, N. dan Suwandi. 1989. Pengaruh dosis dan waktu aplikasi pemupukan fosfat pada tanaman bawang merah kultivar Sumenep I. Pertumbuhan dan hasil. Bull. Penel. Hort. XVIII (2): 98-106.

Hidayat, A. dan R. Rosliani. 2003. Pengaruh jarak tanam dan ukuran umbi bibit bawang merah terhadap hasil dan distribusi ukuran umbi bawang merah. Lap. Hasil Penel. Balitsa Lembang.

Hidayat, A. 2004. Budidaya bawang merah. Beberapa hasil penelitian di Kabupaten Brebes. Makalah disampaikan pada Temu Teknologi Budidaya Bawang Merah. Direktorat Tana. Sayuran dan Bio Farmaka, Brebes, 3 September 2004.

Hidayat, A. dan R. Rosliani. 1996. Pengaruh pemupukan $\mathrm{N}, \mathrm{P}$ dan $\mathrm{K}$ pada pertumbuhan dan produksi bawang 
Tavi Supriana. et al. Pemberdayaan Petani Bawang Merah Melalui Penerapan SPO...

merah kultivar Sumenep. J. Hort 5 (5): 39-43.

Hidayat, A., R. Rosliani, N. Sumarni, T.K. Moekasan, E. S. Suryaningsih dan S. Putusambagi. 2004. Pengaruh varietas dan paket pemupukan terhadap pertumbuhan dan hasil bawang merah. Lap. Hasil Penel. BalitsaLembang.

Hilman, Y. dan Suwandi. 1990. Pengaruh penggunaan pupuk nitrogen dan fosfat pada bawang merah. Kerjasama Balai Penelitian Hortikultura dengan Petrokimai Gresik.

Lestari, P. I. 2009. Kajian Supplay Chain Management. Analisis Relationship Marketing antara Peternakan Pemuliaan Farm dengan Pemasok dan Pelanggannya: Institut Pertanian Bogor.

Marid E. E. and M. R. Vega. 1971. Duration of weed control ad wild competition and the effect on yield. Phil. Agric. 55: 216-220. Muhammad, H., S. Sabihan, A. Rachim, H. Adijuirana. Penentuan batas kritis sulfat untuk bawang merah di tanah Vertisol, Inexprosal dan Entisal di Kabupaten Jeneponto. J. Hort. 11(2): 110-118.

Nazaruddin. 1999. Budidaya dan pengaturan panen sayuran dataran rendah. Penebar Swadaya.

Nurmalinda dan Suwandi. 1995. Potensi wilayah pengembangan bawang merah. Teknologi produksi bawang merah. Puslitbang Hortikultura. Badan Penelitian dan Pengembangan Pertanian. Jakarta.

Pujawan, I Nyoman. Supplay Chain Management. Edisi Kedua. Guna Widya. Surabaya.

Rudiyanto, D. 2013. Analsis Supplay Chain Manajemen Ghetuk Pisang. Universitas Brawijaya. Malang.

Said, A. I. 2006. Produktivitas dan Efisiensi Dengan Supplay Chain Management. PPM. Jakarta.

Samuelson, P. A. Dan W. D. Nordhatus. 2003. Ilmu Mikro Ekonomi (diterjemahkan oleh Nur Rosyidah, Anna Elly dan Bosco Carvalo). PT Media Global Edukasi.

Setyowati. 2005. Analisis Penawaran Jagung di Kabupaten Wonogiri. Jurnal Sosial Ekonomi Pertanian dan Agrobisnis Vol 3 No 1 September 2006. Jurusan Sosial Ekonomi Pertanian Fakultas Pertanian Universitas Sebelas Maret. Surakarta.

Soekartawi. 1993. Prinsip Dasar Ekonomi Pertanian: Teori dan Aplikasi. PT Raja Grafindo Persada. Jakarta.

Sukirno, S. 2004. Teori Pengantar Mikro Ekonomi: Edisi Ketiga. PT Raja Grafindo Persada. Jakarta.

Sukmawati, D. 2013. Analisis Supplay Chain Management Pakchoy Hijau (Brassica junce. L)(Studi Kasus pada Komunitas Organik Brenjonk, Desa Penanggungan, Kecamatan Trawas, Kabupaten Mojokerto). Universitas Brawijaya. Malang.

Sunarjono, H. H. 2004. Bertanam Tiga Puluh Jenis Sayur. Penebar Swadaya. Jakarta,

Stallen, M. P. K. and Y. Hilman. 1991. Effect plant density and bulb size on yield and quality of shallot. Bul. Penel. Hort. XX Ed. Khusus (1) 1991.

Sumarna, A. 1992. Pengaruh ketinggian dan frekuensi pemberian air terhadap pertumbuhan dan produksi bawang merah. Bull. Penel. Hort. XXIV(1): 6-15.

Sutarya, R. dan G. Grubben. 1995. Pedoman bertanam sayuran dataran rendah. Gadjah Mada University Press. Prosea Indonesia - Balai Penel. Hortikultura Lembang.

Suwandi, R. Rosliani dan T. A. Soetiarso. Perbaikan teknologi budidaya bawang merah di dataran medium. J. Hort 7 (1): 541-549.

Wibowo, S. 2001. Budi Bawang: Bawang Putih, Merah, dan Bombay. Penebar Swadaya Medan. 